東南アジー歷史と文化一 No. 21, 1992

\title{
日タイ同盟下の軍費交渉１941～1944
}

\author{
村嶋 英治
}

はじめ に

1941年12月 8 日，日本軍がタイに進駐し，12月11日に日タイ同盟が合意されて以来 敗戦に至るまでの駐タイ日本軍の軍費は全てバーツを用いた。このバーツ雪費は日タ イ同盟条約を根拠として日本大使館がタイ政府と半年每に交涉して調達し，その用途 は日本軍の給意のための米や肉牛等の購入から作戦用の鉄道，道路，飛行場，陣地の 建設留に至る駐タイ日本軍のタイに㫣ける一切の経費であった。それ故に思いどおり

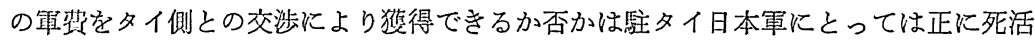
問題であった。

閉戦後一年程度の期間は酫タイ日本弿の数も少なく大規模工事もなかったので軍費 額は多くはなかった。しかし1943年以後になると作戦用の諸工專が開始され，このた めに茞も増強され，加觉て戦時インフレも悪化したので，軍費要求額はウナギ登りに

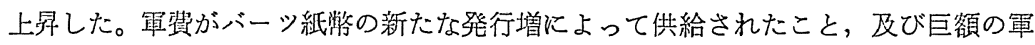
贸が輸入の限られた狭险な市場に投じられたことによって物価の急腾がもたらされ た。

日本侧のバーツ電費要求に対し同盟国タイの協力ぶりは物足りぬものであった。 1941年12月20日に成立した第 1 回軍費協定ではローン形式をとり金塊による決済が約 束された。そののち 42 年 5 月に特別円に関する合意が成立すると日本側は特別円を対 侕としてパーツ婜费を必要なだけ調達できると期街した。一方，タイ側は特別円を最 大限国前のために利用しようと梌めた。彼らは戦争前半期に执いては国内通貨の安定 あるいは国内工菜の育成等を理由として，日本から得た特別円を代価として金塊，機 栈・物资，武器などの㒛入を強く求めた。戦局が悪化した戦争後半期になると軍費を めぐる日，タイの利害対立が明白となる。日本軍は戦場のタイ接近とともにより一層 の雪資を求めるが日本侧にはタイに見返りを与える能力は極めて減少して叔り，一方 タイ側は激增する簐费支出の国民生活への悪影響は単に経済問題にとどまらず政権へ 
の国民の不支持を高めることになることを危惧し，また日本の敗戦で特別円が無価值 なすのと化すことをも恐れて，でき得る限り央費供給を㧕克，かつ特別円ではなく金 塊や物品による見返りを熱心に求めた。更には既に日本銀行にタイ政符の所有権を明 示するイヤマークがされたのち保管されている金塊までも戦中の危険を冒して本国へ の現送を実現しょらと努めた。

軍費問題がタイにとって如何に重要であったかは，1943年10月から翌年 7 月までピ ブーン政権末期の外相であったディレーク・チャイヤナームがその回想録で，上記外 相時代の回想としては軍費交渉のことのみしか記していないことに示される(1)。ま た日本軍にとっても軍費の死活的重要性は，タイが軍费に協力しなければ武力処理も 止むを得ずと考えられたほどのものであった。1945年の軍菼について㹂タイ日本軍で ある第39軍の参謀をつとめた原寿雄（少佐）は次のように回想している。即ち

日本軍がタイ国に要求していた軍費は 5 億バーツを上回るものであってインフ レをもたらすし，もらけるのは上層部と蕉僑ということで哜会通過が因難視さ れ，もし通らなければ力を行使せねばならぬと大使を通じて談判をすると其に军 はその準備をしていたことであった(2)。

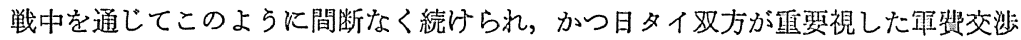
は，日タイ同盟の奏態を理解するための最良の資料であると洘えられる。本稿は数少 ない日本側資料に比して豊富に保存されているタイ侧凟料を用いて(3)日タイ用埅交 渉の過程を明らかにし，よって日タイ同盟の奏態の一侧面に迫ることを課題と寸る。

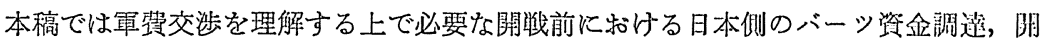
戦後のワニット経済使節団による日タイ経済交渉をまず概観し，次いでタイ外交文留

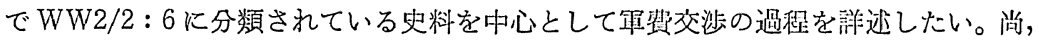
紙数の制限のため1944年上半期分の軍資交造までを刘象とし，その後の交涉は别樎に 眐る。

\section{I 塸戦体制とバーツ資金調達}

日本にとってタイが政治的軍事的に重要性をあつようになったのは武力南進筷が追 求されるようになる1940年のことであるが，経瀜的にタイの重要性が急浮上したのは 1941年 7 月の米英蘭等の対日資産碀結を契機としてであった。これ以前の日タイ経淆 関係は微々たるものに過ぎなかった。1938/39年についてみると，タイの年間粆仙䫈 2 億44.2万バーツのらち73パーセントが英国及びその属領に輸出され，対日鍮出はわ ずか1パーセントの239万バーツに過ぎなかった。同年のタイの翰入 1 億2963万バーツ 
東南フシフー歷串と文化一 No. 21, 1992

についてみても，英国及び属領からの翰入が60パーセントを占め，日本からの翰入は 15パーセントであった(4)。タイ経済は英国の圧倒的影響下にあった。それは(1)翰出 貿易の 7 割以上がポンドブロック向けであるばかりでなく，(2)バーツ貨はポンドにリ ンクされポンド為替本位制をとっており，(3)英国は錫鉱床の約 7 割，チーク材の約 4 割見当を押えており，かつ，(4)タイ国の商業組織不備なるため組織の完備したシンガ ポール，ペナンに錫捈石，ゴム等の大部分が流れていた(5)，ことに示される。

日本のタイからの翰入は微量であり，手持のポンドを売ってバーツを取得し品物を 調達する方法をとっていた。日タイ間貿易はポンドを通じて取引が行なわれていたの である $(6) 。$

ところが1941年 7 月の英米關の対日資産凍結は, 日本経済にとってタイの重要性を 飛躍的に高めた。日本の貿易相手は極めて限定されることになったため，戦略物資で あるゴム，錫，米を大量にタイから輸入せざるを得なくなったからである。しかし同 時にポンドでの従来のような決済は不可能となったのである。

のちに日タイ軍费交渉で日本側の中心人物として衝に当ることになる新納克己は 1942年 7 月外務省通商局長時代，次のように畫いている。「昨年 7 月の対日資産凍結 の实施を契機として我が対外貿易は円ブロックと仏印，泰を除いては全面的に杜絶 し，戦略物資の獲得は困難となり，……(7)。タイ産の戦略物資の価值の急上昇に際 し日本側は「タイの錫，ゴム等も戦時下の重要資源として東亜共栄のために使用さる ベく，他に流出するやうなことがあってはならない。蘭印からこれら物資が得られな くなった現在，その輸出は全部日本に向けられればならぬ」(8)といら考觉で，日本 のみにゴム，錫を独占的に供給するよらタイ政府に求めたが，ディレーク外相やアド ウン副首相が反対し日本との間の合意は成立をみなかった( 9 )。しかし日本商社によ るタイでのすさむじい買い付けで日本側は大量のゴム，錫，米の取得に成功した。 1941年のタイの対日輸出額は 1 億940万バーツに急増し, タイ輸出額の37.7パーセン トを占めるまでに達した(10)。

ところで，タイからの買いつけの必要が急上塌すると同時に，ポンドでの決済は不 可能と化していた。当時大野龍太日本大蔵省頋問の下でタイ国で日タイ経済調整に携

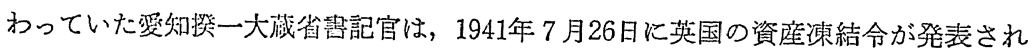
たのちポンドが決済に使えなくなった日本側の困難を次のように語っている。

さうすると，ポンドを通してバート資金を調㒓するといふことがその日から出 来なくなってしまった。当時は丁度米の出迴る時期でありましてバンュックに入 るメナム河の河上には日本の運送船が一杯入って参ります。そして何チトンかの 
米を連日積込んで居る。ところが資金調達の途がなくなったのでとの日の苦力の 支払から艀舟の侓船料まで場合によっては払へなくなるといふ状態值面したわ けであります。実に大変なことになったので，差当りこれは泰を承知させて金を 借りるより外に仕様がない(11)。

このため大野䫏問ら日本政附代表とタイ国大蔵省に属するタイ国立銀行局（Thaj National Banking Bureau) との斡旋(12)で，横浜正鈈銀行とタイの銀行 3 行からな る銀行団との間に1000万バーッ（邦貨約1600万円）の借款契約が1941年 8 月 1 日成立 した。1000万バーツを当座借越し升済期限到来時に貸越牫高があるとさはタイ銀行団 に対し金イヤマークによって決済をすることを約したのであった。交渉に拈いて大野 顧問は円による決済を求めたがタイ側の大蔵省碓問詠タイ国立銀行局の長であるウィ ワットチャイ殿下らはあくまで金塊による決済を主張して虽らず(13)，立垛の弱い日 本側はそれに応じたのである。

前述のよらに1941年には1億バーツを超えた日本のタイからの罪いつけに比せば， 1000万バーツのクレジットは焼石に水であった。大野顧問らはタイ大荿省と交涉し更

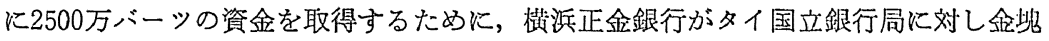
2500万バーツ相当分を売却することにし，その協定が1941年 8 月26日に成立した(14)。 タイ側がバーッ貨と引き換えに金塊の賟入に応じたのは金本位制にもどりたいという 希望があったためであろう(15)。この金塊について大野顧問は「金壳却スルモ金八本

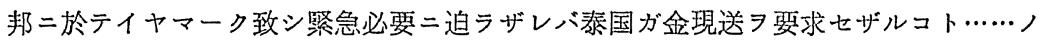
覚書」をプリディー・パノムヨン墭相に求める希望(16)をもっていた。これに刘しプ リディーは金のタイへの現送に固熱した。日本僛はプリディーが非友好的であると怒 ったが(17)バーツ資金の欲しい日本侧はこれに応じざるを得なかった。閒饯前の経消 諸交渉では日本側は，タイ側が泰・仏印紛争調停の返礼として文灯的に応してくれる ものと期待したが，タイ側の対応は日本侧の期街ほどではなかった(18)。しかし日本 側の要求を全く拒否するものでもなかった。更にタイ侧は日本侧に求められ12月6日 に金賗入の方式により日本へ2000万の貿易用バーツ資金芯提供することを約した。こ れらのバーツ資金に対し1941年 8 月28日から1942年4月1日までの間に，5回洲5500 万バーツ分の金1813万4071.6グラムが日銀に特いてイヤマークされ，そのらち431万 879.8グラムは1941年9月15日にタへに現送された(19)。

この貿易用バーツ資金に加克，同年12月 8 日以嵝日本軍がタイに進匯すると，タイ 側は日本軍に軍票は使わずバーツを使用することを求めたため(20)，日本隺は很熊用 のバーツを必要とすることとなった。1941年12月20日に，1941年12月と1942年上半期 
東南フジー藲史と文化一 No. 21，1992

表1 駐タイ日本軍の軍蕒使用高と決済方法

(単位 : ヘーーッ)

\begin{tabular}{|c|c|c|c|c|c|}
\hline & \multirow{3}{*}{ 軍費使用高 } & \multicolumn{3}{|c|}{ 決消方法 } \\
\hline & & & \multirow[b]{2}{*}{ 特別円と交顛 } & 売 & 却 \\
\hline & & & & 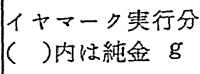 & $\begin{array}{c}\text { イヤマーク } \\
\text { 末実行分 }\end{array}$ \\
\hline \multicolumn{2}{|c|}{ 1941年12月一-42年 6 月 } & $15,001,083$ & \multirow{3}{*}{$29,500,000$} & $\begin{array}{c}15,001,083 \\
(4,896,246.10)\end{array}$ & \\
\hline 1942年 7 月一 & 12月 & $40,500,000$ & & \multirow{2}{*}{] $\begin{array}{c}29,000,000 \\
(6,041,666.70)\end{array}$} & \\
\hline 1943年 1月一 & 6月 & $18,000,000$ & & & \\
\hline 1943年 7 月一 & 12月 & $143,200,000$ & $113,200,000$ & $\begin{array}{r}30,000,000 \\
(6,250,000.00)\end{array}$ & \\
\hline 1944年 1月一 & 6月 & $275,000,000$ & $225,000,000$ & $\begin{array}{r}35,000,000 \\
(6,055,364.10)\end{array}$ & $15,000,000$ \\
\hline 1944年 7 月一 & 12月 & $239,000,000$ & $219,000,000$ & $\begin{array}{c}20,000,000 \\
(3,460,208.80)\end{array}$ & \\
\hline 1945年 1月一 & 6月 & $470,000,000$ & $450,000,000$ & 0 & $20,000,000$ \\
\hline 1945年 7 月一 & 8月 & $319,000,000$ & $299,000,000$ & 0 & $20,000,000$ \\
\hline \multicolumn{2}{|l|}{ 計 } & $1,519,701,083$ & $1,335,700,000$ & $\begin{array}{c}129,001,083 \\
(26,703,485.70)\end{array}$ & $55,000,000$ \\
\hline
\end{tabular}

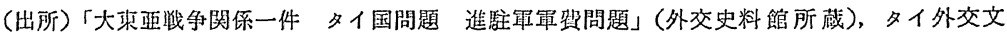
趐WW2/2:6/2, WW2/1:6/5 及び Thanakhan haeng Prathet Thai, 1961, p. 80 ょり 籍者作成.

の簐賣に関して日本大便館とタイ政府との間に協定が成立した。これが日タイ間最初 の軍資協定である。この協定では 6 力月分として 8000 万円相当額を限度とするバーツ をタイ国立銀行局より当座借越の形式により借入れ，1942年 7 月 1 日に特ける借入残 高については米国市場の金洒格を基準として金イヤマークにより決済することとし た。またイヤマークした金塊は日銀において無料保管し，現送が合理的安全性を以っ て帮行し得るに至った時は現送費及び保険料は日本側負担にて速やかにタイ政府に引 渡すことを約した。この期間の軍費として実際に使用した1500万1083バーツにつき表 1 のように金イヤマークがされた(21)。この第 1 回軍費では日本は前述の貿易用バー

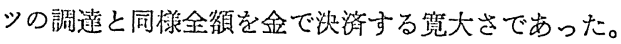

\section{II 日タイ経済交渉と特別円協定}

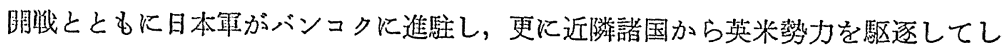

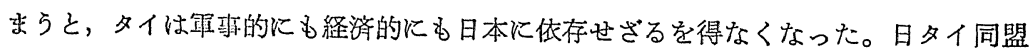
が12月11日，坪上貞二大使，ピブーン首相間で合意され同21日に正式に調印された。 翌年1月25日タイは英米に宣戦布告した。経済面でもタイの輸出入先は日本のみとな 
り，日本の立場は強くなった(22)。1942年 1 月12日には国務大臣で大蔵大臣代理でも あるワニット・パーナノンが坪上大使を訪問し，近く英米に対しタイが宣戦すれば在 英米の通貨発行準備金 2 億バーツが敵産として没収される，これはタイの通货潐備の 3 分の 2 に当るのでタイ通貨の安定のため 2 億バーツ相当の金塊を日本より借入れた いと述べた(23)。この申し入れによって日タイ経済交渉が開始されることになる。本 件を坪上大使が日本政府に請訓したところ，1月30日に対タイ経济交渉に関する日本 側の方針として次のような訓電が到着した。即ら，2 億バーツの借款には応ずるが 「大古亜共栄圈内ノ通貨 シ居レリ米英卜経済, 交通ノ断絶セル今日金八其ノ重要性

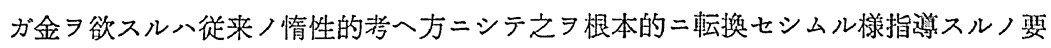
アルモ若シ泰側ガ後出ノ我方諸要求 7 受諾シタル後是非共金 7 要求シ交逤上已ム ザル場合ニハ右ノ金ヨ発行準備トシテ本邦内ニイヤマークシ之ヨ現这セザルコトヨ条 件トシテ募債金額ノ一部ョ金ヨ以テ応ズル用意アリ」とし,「後出ノ我方諸要求」と は第 1 に，バーツを円にリンクせしめその比率は 1 対 1 とすることであり，第 2 に, 速やかに中央銀行を設立し同行に有力なる日本人顧間を置くことであった(24)。バー ツを36パーセント切下げることを意味する第 1 の要求はタイ米などのタイからの輸入 価格を引き下げることを第一次的目的とし(25), 第 2 の要求の目的は, タイ中央銀行 設立準備のため1942年 1 月に在タイ日本大使館に派遗された日銀の藤㶚徳三郎の回想 によれば「最初の仕事が，タイ側に新しく中央銀行を設立させ，従来大蔵省通货局が 政府紙幣を発行していた制度を改莗させようといらことで，その狙いはバートを等洒 にした上で，両国中央銀行に預け合勘定を設け，我が軍の曘費調達を容易ならしめよ うというにあった」。(26)

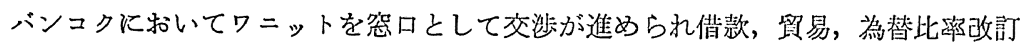
につき 3 月30日までに基本的了解に達したのち，4月 4 日にワニットを首唐としウィ ワットチャイ大蔵省顧問，チャイ・プラティーパセーン中传（外務省副次官）からな る経済使節団が訪日した。バンコクでの了解を基礎とした東京での交渉により4月21

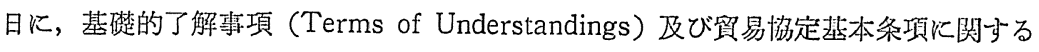
了解事項が署名され，同日，円バーツ等価決定の口頭声明も発表された。5 月2 日に は日タイ間支払の特別円決済に関する協定覚望 (Memorandum of Agreement) 及び それに関する了解事項 (Confidential Understanding) が署名され，6月18日には借 款協定，特別円決済に関する協定，借款に関する覚畫が署名された。

ここでは軍費交渉に関係の深い特別円及び中央銀行の設立についてみて括こら。 
巢荫アシシア一歷史と文化一 No. 21, 1992

4月21日の日タイ間の基碟的了解事項は「日本国及泰国間ノ貿易上及貿易外ノ一切 ノ決済八特別円二依ルベシ」と定め，5月2日の協定覚書において「特別円』ナル 文言八日本卜翡国トノ間ノミナラズ泰国ト其ノ他ノ諸国又八諸地域……トノ間ノ一切 ノ支払ノ洪済二使用セラルル日本円ラ謂フ又『特別円』ハ必要二応ジ純金一グラムニ 付四円八十銭ノ割合ニテ金二振替へ得ベキモノトス」とした。協定覚書案作成におい てタイ側は「支払の決済に『自由』に使用せられ必要に応じ『自由』に金に振替へ得 る (freely convertible) あのとする」と「自由」という文言を入れることを希望した が日本侧はこれに強く反対した(27)。その結果「必要ニ応ジ」なる文言の意味を明ら かにすることとなり同日, 次の諒解事項に合意した。即ち,「特別円八合理的ナル要 求アリタル場合八同協定覚書二於テ同意セラレタル価格二依リ金二振替へ得ルモノト ス但シ現在ノ状況二於テハ斯ル金へノ振替ハ其ノ必要ナキモノト諒解ス」と。

協定覚畵及び諒解事項により日タイ間支払に扣ける特別円決済の原則は定まった。 その洖施のために 6 月18日タイ国大蔵省と日本銀行との間に特別円決済に関する協定 が結ばれた。その内容は以下の通りである。

（1）泰国大蔵省八日本銀行本店二泰国国庫特別円勘定ト称スル一般勘定 $\ni$ 開設スル コト

（2）棌国大藏省ガ同国為替集中制度二依リ売却シ又八買入レタル円為替ノ受渡八前 記勘定ノ借記又八貸記二訨リ為サルルモノトスルコト

（3）泰国大蔵省八泰国二於ヶル日本側銀行（具体的には横浜正金銀行一村嶋）ノ正 常ナル取引 何時ニテモ前記勘定二貸記セラルベキ円货 $尹$ 対価トシテバート貨 $\ni$ 供給シ……。

特別円協定によって日本は貿易层を金で決済したり，バーツ資金を得るために金を 売却する必要がなくなった。当面金に振替える必要はないと約させた特別円と交換に バーツ資金が容易に獲得できるようになったのである。この原則は後にみるように 1942年11月24日の曘費に関するA協定で当採用された。

特別円と交換にバーツ資金を供給させるため日本側は円を通货発行準備金としてバ ーツ学発行する中央銀行の創設を求めた。日本が要求する以前からタイでは独自に中 央銀行設立の準備をして㳘り，1940年 5 月13日にタイ国立銀行局が開業していた。し かし1942年 2 月に打ける日本の要求の時点では同銀行局は開業後日も浅く中央銀行機 能のほんの一部を担っているに過ぎなかったので, タイ側は誰も中央銀行設立の時機 に避したとは访えていなかった。そこに日本が設立要求を出した。もし設立が遅れれ ば日本人䧹問を受け入れざるを得なくなり，タイ金融をコントロールされる伦惧が高 
まった。そこでタイ政付は既に設立に着手しているからとして㕍問受け入れを拒否す ることにした(28)。タイ側は日本側の設立要求を知ると直らに設立奏行に着手し， 1942年 2 月17日にはウィワットチャイ大藏省䫏問が設立要網を作成し，3月4日の閣 議は同要綱を基礎にした中央銀行法案を承認した。更に4月 6 日の国会で早くもタイ 国銀行法を成立させた(29)。同年2～3月のバンコクに㸱ける経济交渉で日本侧は勃抄

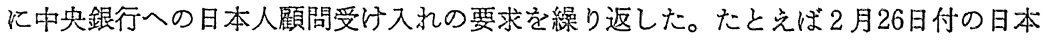
政府から大使館への訓霄は「中央銀行ノ日本人顧問八名称ノ如何二拘ラズ夷現シ度キ ヨ以テ顧問問題落着迄ハ中央銀行 設立セシメザル様取計ハレ度キコト」(30)を求わ， タイ側の単独での急速な設立にブレーキをかけようとまでしている。結局日本人顦問 問題心タイ側の強い反対で実を結ばなかった。タイ国銀行は1942年12月10日に開業し た。

それに先立ち，日本円も通货発行準備金とすることが非常時通货法に基く6月15日 付大藏省令公布により可能となった。6月18日の借款協定により取得した「特別円と 同一の性格」を有する 2 億円はこの法改正をらけ発行準備に加えられた。こののら前 述 6 月18日の特別円決済協定や11月24日以後半年每に結ばれた電留協定により日本侧 からバーツ資金が求められる每に，その対侕として支払われる特別円を染借金として 新たな緍幣が増発され(31)日本側に供給された。この結果，タイの通货発行盢は1941 年11月末日の約 2 億7500万バーツから1945年 8 月末日には19億9265万バーツ余に增大 した(32)。この増加の大部分は表 1 からみて軍費供給に迊因している。

\section{III特別円及び金売却による䨵費調篷}

\section{1942年下半期軍費協定}

バーツ軍費を調達するために特別円が対価として用いられた最初の協定は1942年下

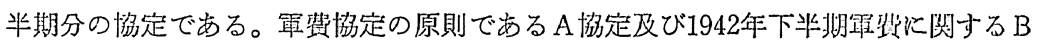
協定が成立したのは，1942年も押し詰まった11月24日のことで岁った。この交渄は非 上大使が42年下半期分として5100万バーツを求め，その決済を4月21日の甚磪的了解 事項兴㮛拠として全額特別円によるよう求めたことに炲まった。これに刘し7月15日

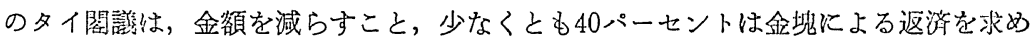
上は特別円めた。ウィチット外相が閣議決定の方針に基き埭上との交涉に当った。坪 ることを決柱金や外貨に転換できるらえに，転換しなければ日銀から利子も支払われ るから金塊よりる有利であるとして特別円による決済を主張した。タイ侧は41年12月 から 7 カ月間の実際の電費支出は1200万バーツ（正しくは表1にみるように1500万 
東南フシフー監史と文化一 No. 21, 1992

余）に過きなかったからとして減額を求めるとともに通貨発行準備としては金が欲し いと寒らなかった。坪上は3650万バーッル要求額を減し，この軍費と交換にタイ側に 支払われる特別円のうち1800万円まで金売却することに譲歩した。その際坪上は金売 却は今回限りで以後の軍費については特別円のみで決済するという原則をタイ側が確 認すること及び泰緬鉄道建設費用として400万バーツの追加を求めこれは全額特別円 で決珮することを要請した。しかしタイ侧は坪上の求める原則の確認には応じなかっ た(33)。

タイ側が応じなかったのは同年4〜6月の東京での経済交渉において，日本側が一切 の決消は特別円によるといら原則を示したのに対し，タイ側は軍費はそれに含まれな いと抵抗した(34)という経緯があったためである。1942年11月24日，A，Bの 2 協定 (Arrangement) が坪上大使とウィチット外相間で署名された。A協定は軍費調達の 基本原則であり，軍事的経済的相互支援を約した日タイ同盟条約に従って第 1 条，タ イ国政府は簐用鉄道建設経費を含む日本軍の草費をカヴァーするため特別円を対価と してバーツ資金を供給する，第 2 条，日本政府はタイ国政府の保有する特別円を対 洒として an appropriate amount の金塊を売却する, と定めた。また口上書（Note Verbale）によりA協定第 2 条にいら an appropriate amount とは提供されたバーッ 資金の約50パーセントを意味することが双方で了解された。B協定では，A協定に従 い1942年下半期分軍费としてタイ側が4050万バーツ（内400万は鉄道用）を特別円を 刘価として供給すること，このらち2000万円につき金を売却することが約された(35)。 更に同年12月25日タイ国のボリパンユッタキット蔵相と坪上大使との間にB協定実施 のための細目協定（No.1）が結ばれ，タイ政府に 1 グラム 4 円80銭で売却された金 はタイ国銀行の財座としてイヤマークされ，日銀に無料で保管されること，合理的安 全性 (reasonable safety) を以って日本からタイへの金現送が可能になった場合，日 本政府は速やかに現送費，保険料は日本側負担で現送することを約した(36)。

1942年下半期軍費交渉はワニット経済使節団㷌国直後に開始され，途中需营が不足 し9月23日に700万バーッを限度とする当坐借越によって補い，11月24日になって漸 く成立した。タイ侧の粘り強い交渉で，日本侧が東京でワニット経済使節団に合意さ せたはずの特別円による一切の決済の原則，及びタイ側の取得した特別円は現在の状 況では锌に振替る必要はないといら約束は早々と反故に近くなった。バーッ軍費は全 類，特別円との交換という形式で供給はされるる゙，同時に特別円の約半額を対価とし て金壳却がなされることになったのであるから。 


\section{1943年上半期軍費交渉}

42年下半期の軍費交渉が成立すると次期軍費の交渉期日がすぐに迫ってきた。B協 定による軍費は年末に至っても相当残余があったので12月31日，日本側はウィチット 外相にB協定の 6 力月間延長を申し入れた。外務省は大蔵省と協議ののち1943年 1 月 11日に延長を認める回答を石井康臨時代理大使に伝觉てさた(37)。次いで 2 月 6 日， 日本側は43年上半期軍費として新たに1800万バーッをタイ外相に求めた(38)。外相は

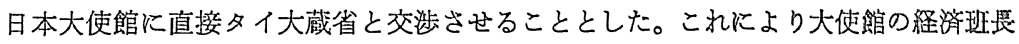
新納克己参事官はウィワットチャイ大蔵省顧問を訪ねた。同大蔵省顧問は，この会見 で新納に1800万バーツの内訳を求め，一方新納は $\mathrm{A}$ 協定及び口上罯による全党却の代 りに緔績機などの機械の売却で如何と打診した。同顧問は 2 月11日付で外相に報告 し，大蔵省の意見としては金壳却の原則を改めるべきではないこと，機珹偝入のため には翰出超過の結果特別円の手持が十分あるので日本が軍费を要偝してさた機会を㭪 え軍費の返礼として機珹を売るよう求めるべきであると提䓩した(39)。

2 月26日藤澤日銀代表が大蔵省顧問を訪ね 1800 万の内訳として軍用跌道建陪翼が

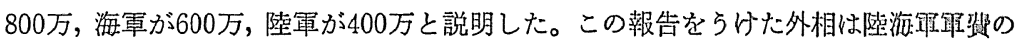
詳細を日本側に質問した。3月6日新納が外相を訪ね軍損の詳細を口頭で説明すると ともに金売却に代わる機械売却を正式に提案した。外相は曘贸の供給のためには新し く通货発行が必要だが50パーセント程度の金準供がなければ通货の安定性は保てない と答え, 新納は金は今日では発行準備には不要のものであり, タイが全売却を求めれ ば日本は金生座のために贵重な資源を配分しなければならない，日本政府はタイ政府 が金塊に固际することに大きな不信感をもっていると語りタイ侧の格打を促した(40)。

3 月19日，大東垔省の日タイ経済関係の担当者がコンティー留記官に渐納が㠫求し

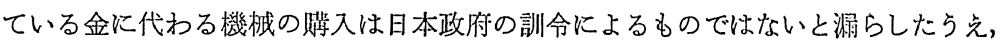
A協定の存在にも拘らず新納が強行しょらとしていることに買憾の意を雯したとディ レーク駐日大使が本省に無線電話で知らせてきた(41)。同日付でウィチット外相は报 上大使あてに軍費についての覚書を作成した。その中で，A協定と口上热は策贸につ いての基本原則であり，それが安易に変更されるようではタイ政府とタイ国民の日本 への信頼が傷つけられる，確かに日本からの機珹供給は強く欲している，既に䒜約が 成立しているのに生産余力がないとか船腹不足とかを理旺に未だ受頒してないケース も多い，これらは既有の6000～7000万の特別円で期入したい。また昨年のA汾定交涉 中，機械と兵器との睍入を求めたのに対し日本側は軍費とは別個の問題たからリンク 
東南フシシフ一歷史と文化一 No. 21, 1992

させるなと反対したではないか。日本側はタイは戦殿のために効果的協力を日本に与 えるべきであると繰り返し発言しているが，タイ側は日本の要請を断ったことはなく 日本の欲するすのを与えるために最善の努力を尽している。故に日本側はタイに同情 して援助すべきであり(1)タイ通货の安定のため軍費の50パーセントの金売却をすべき であり，同時に(2)戦争遂行上必要な物資生産のために工業用機峨も売却すべきであ る(42), と述べた。

長びく交渉のため日本軍の手持軍蒷は残り少なくなり 3 月23日藏相は外相に, 日本 侧が370万バーツ余を残すのみになったと通知してきたことを報告した。同日，約束 により外務省を訪ねた新納に外相の前述 3 月19日付覚書が経済局長より手交された。 覚暂を読んだのち新納は経消局長に，金賏入の代わりに機械購入を求める件は取下げ る。しかし金 1 グラム 4 円80銭の価格は市場価雒と比して安すぎるので At a fair priceに改訂したい，もしタイ侧がこれに応じなりれば東京の当局者は「やはりタイ は日本に協力していない」と考えるたろう(43)と告げた。外務省は大蔵省に意見を求 めた。3月27日付で蔵相は1800万バーツの軍費額は認めてよいが，金価格を1942年 5 月 2 日の協定觉書で金 1 グラム 4 円80銭と定めたのは，日本側からアメリカの金価格 を基準にすることを提案した結果によるものであるから，従来の洒格を堅持するよう にと答えてきた(44)。

4月 7 日に新納は，3月19日付の外相覚書に答える覚書を持参し外相に面会した。 新納は覚需の中で(1)外相が日本との協力の意思が欠如するなどといらことはありえな いと吉ったことを微迎する。自分自身も両国の友好関係に寄与することを喜びとして 扣りこの精神に批いて金塊よりも機峨の方がタイ国の役に立つと考兄て提案した。 しかし軍費交渉のこれ以上の革れは日本の陸海軍の困難を增し双方の一般的友好関係

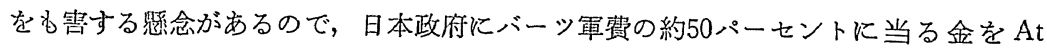
a fair price で売却するよう意見具申する用意がある。(2)私が金より機械の壳却を提 案した理由は機械によって生库される工業製品の供給が物価上䅫を抑え国民の通貨へ の信頓が增すと考えたからである，などと述べ，日本の陸海軍の活動が軍費不足によ り制約されることがないよう金価格決定は棚上げし，とりあえず簐費交涉を妥結する ことを求めた(45)。外相はこれに反対し，今回は 1 グラム 4 円 80 銭の従来通りとし次 回は別に交造しようと提案した。新納はこれに同意し漸く交渉は成立することとなっ た(46)。外相の発言を日本侧は䛊歩と理解したが外相発言は䨋はピブーン首相の命令 でタイ侧の次回電费交渉方針が既に変更されていた結果であった。3月30日タイの閣 議はインフレ開題を検討し，インフレの原因を(1)タイからの対日輸出額に比し日本か 
表 2 タイ輸入品物価指数

\begin{tabular}{|c|c|c|c|c|c|c|c|c|}
\hline & $\begin{array}{l}\text { 峨 } \\
\text { 物 } \\
\text { 類品 } \\
\text { 品 }\end{array}$ & 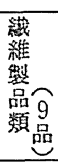 & $\begin{array}{l}\text { 雑 } \\
\text { 货 } \\
\text { 類品 } \\
\text { 品 }\end{array}$ & $\begin{array}{l}\text { 食 } \\
\text { 料 } \\
\text { 品合 } \\
\text { 類品 }\end{array}$ & 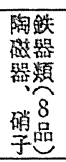 & $\begin{array}{l}\text { 金 } \\
\text { 属 } \\
\text { 謴品 } \\
\text { 品 } \\
\end{array}$ & $\begin{array}{l}\text { 蔡 } \\
\text { 品 } \\
\text { 烦品 } \\
\end{array}$ & $\begin{array}{l}\text { 合65 } \\
\text { 品 } \\
\text { 品 }\end{array}$ \\
\hline 1940年12月 & 100 & 100 & 100 & 100 & 100 & 100 & 100 & 100 \\
\hline 1941年 6 月 & 129 & 137 & 153 & 113 & 123 & 135 & 119 & 130 \\
\hline 12 月 & 180 & 198 & 262 & 137 & 180 & 180 & 125 & 181 \\
\hline 1942年 6 月 & 465 & 368 & 428 & 207 & 293 & 364 & 276 & 341 \\
\hline 12 月 & 793 & 455 & 630 & 353 & 366 & 707 & 375 & 518 \\
\hline 1943年 6 月 & 1272 & 754 & 869 & 622 & 474 & 1092 & 890 & 860 \\
\hline 12 月 & 1517 & 983 & 914 & 774 & 618 & 1594 & 1217 & 1001 \\
\hline
\end{tabular}

（注）本統計は日本のバンコク○う会の調查による.

（出所）台湾総督府外啝部『南支南洋時報』第38号（1944年 9 月） pp. 96-97.

表 3 バンコクに拈ける消費者物洒指数

\begin{tabular}{|c|c|c|c|c|c|}
\hline & 饮食留 & 住居热 & 被服热 & 䧴 & 総 合 \\
\hline 1941年12月 & 100 & 100 & 100 & 100 & 100 \\
\hline 1942年 6 月 & 119 & 125 & 235 & 157 & 147 \\
\hline 12 月 & 168 & 162 & 374 & 209 & 206 \\
\hline 1943年 6 月 & 217 & 196 & 641 & 276 & 286 \\
\hline 11 月 & 235 & 246 & 654 & 315 & 317 \\
\hline
\end{tabular}

（注）バンコクのタイ人中旅嫁 庭の生活䖵を赴洲として日林

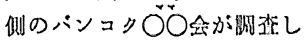
たもの。㡏入に烦る被服踶及 び同じく翰入品で方る医浆贸

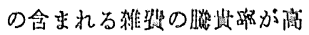
い。

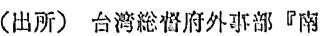

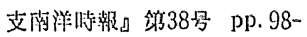
101.

らの工篻製品翰入が少ないこと，及び(2)日本の軍費支出の增大であると判断し今後の 軍費交渉では軍費と交換にタイが必要な商品を日本に求めることを決めた(47)。

ピプーンは直接外相に，次回は金塊の代わりに橙械を背光と命令もしていた(48)。 4月14日の閣議は1943年上半期の軍費として1800万パーツを供給すること，その刘侕 として得た特別円の半分について 1 グラム 4 円80銭で金㞗却をらけることを承恋する とともに，次回は日本が軍費をもっていく場合は交換の物をもってこない限り合意は しないという軍費交渉の新原則を確認した(49)。4月19日外相は坪上大优にC惕定案 を提出し 4 月22日坪上は次のよ5な公文で外相に答光た。即ち，日林政府からの郡令 によれば日本政府は金は通货灾定のために重要であるとは访えていない。しかしタイ 政府の熱心な要望に鑑み政治的若虑から，今回の軍势類の半分まで 1 グラム当り 4 冈 80銭で金を壳却する。但し今後の軍費については新しい甚礎の上で修決することとし そのための方法について直ちに協議を始めることが今回の金壳却の条件であると(50)。

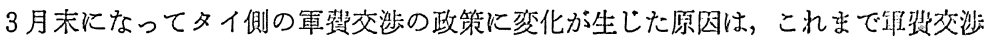

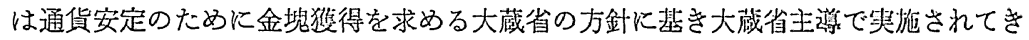


東南アジフー歷史と文化一 No. 21, 1992

たのに対しピブーン首相が自らイニシャティブを発箅するよらになったからである。 ピブーンを動かしたるのは表 2，表 3 にみるようなインフレが国民の経済生活に深刻 な影響を与えるようになってきた現実であろう。

4月18日付でウィチット外相は坪上大使に, 青木大賁覀相訪タイに先立ち協議した いとして私信を提出した。その中でピブーン首相の意を代弁して，首相は国内の経済 問題を最も心配しており，それ故，領土回復問題には二次的関心しかすっていない， 首相はインフレと日常消費物資の欠乏という経済問題を深刻に受けとめておりその原 因は軍費供給のための紙撆增発にあると考光ていると語り，ついては次回の軍費交造 では金売却を求める原則を改め，軍費と同額の機械を求める新原則に合意したいと提 案した(51)。この文畫からも国民の経済生活の悪化に直面したピブーンの関心を明確 に知ることができる。このようにウィチット外相は坪上にタイ側も交龇の方針を転換 することを早々に伝えた。しかしこの転換は日本の望む交渉の「新しい基礎」とは逆 方向のものであった。

\section{N 経済悪化と1943年下半期軍費交渉}

43年下半期の軍費交渉は開始当初より，草漬と機械・物資を結びつけて䆛らぬタイ 側と雨者を切り離して政治的考虙から早急に電費を供給することを求める日本側との 攻防が屡開した。

6 月初, 坪上大使はウィチット外相に重要案件でピブーン首相に面会したいと申し 入れた。外相は坪上に案件内容をたずねたのち，軍費の件は首相に会っても効果はな いと述べ先ず自分と協議するよらに求めた。6月3日に両者は協議した。坪上は政治 的洘愿を求め，両国の最重要求は戦勝であり軍費は戦争に直接必要なものであるから 物品の売買などとは結びつけるべきではないと両者の切離しを求めた。外相は首相の 絶刘に物を取るべしとの政策に忠契に，タイが求めている自動車や鉄道部品それに国 防省関係の物は直接戦埩に必要なものであり，紡績機械など座業用機械もタイの経済 力を高めることで值接戦争に影既するものであると反論した。結局双方参加の委員会 をつくり話し合うことを決めた(52)。

6 月 5 日，日本侧は新納をタイ侧はワンワイタャーコン外務省顧問を代表とする委 員会が開かれた。新納は東京には一部，タイが全面的には協力していないと考えてい る者が存在している，坪上大使が外相に求めたように政治的考虑により合意して欲し い，軍资は単にバーツと特別円との交换をすればよいことであり他の問題をからめる べきではないと主張した。更に日本はタイに経济的援助をすることに斑かではないが 
軍費は急を要し機械の輸入には時間を要するから全く別個の問題として別なに話し合 括うと提案した，しかしワンは別個の合意とするのはいいが両者を同時にサインした いと諆らなかった(53)。

続いて 6 月 10 日開かれた第 2 回目の会議では夕イ側は日本への要求リストを提出す るとともにその場でリストに名を連ねている国防，交通，工粟の三省の局代韭皆が求 めている機珹・物品の必要性を新納に対し説明した。この日も新納は電罣と要求リス トとを結びつけることに強く反対した。ワンは日本軍の当面必要な筆費は当匧贷越の 形式で認める，しかし残りの軍費と機械・物品の売買とは同時に合意したいと主张 し譲歩しなかった，そこで新納が当面必要な曘費として1540万バーッを求めるとタイ 側は額の是非についてチャイが長である日タイ同盟連絡弱務局と永䜅するように求め た(54)。

6 月 12 日坪上はウィチットを訪問し, 従来の曘费交渉では外務, 大成の 2 省のみと 交渉すれば済んだのに新たに日タイ同盟連絡事務局を介在させて交渉を艮びかせかつ 減額しようとするやり方は軍費の緊急的必要性を理解しょうとしない熊度であると批 判した。外相は電費は内閣の承認事項だが閣議でどうして巨額の霍䩀が必要なのかと

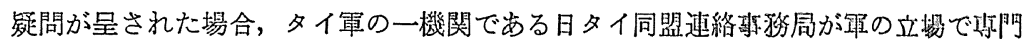
的に検討した額だ答えれば通りがよいと説明した。この席で坪上は，1943年下半期 の軍費要求額を記した公文を外相に手交し正式に要請した。総額は8740万デーッで,

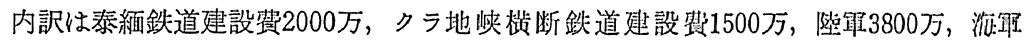
1440万であり，このうち1540万を至急欲しいという内容であった。廷に㘫上はその掦 で注目すべきことを付け加えた。即ち，現在交渉中の機械や物品の他にタイ侧が众坮 を欲するなら日本は売却する用意がある。また東京に保管帅のタイの企塊はタイが現

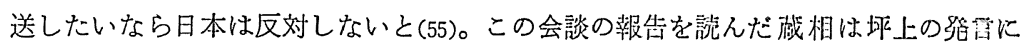
注目した。蔵相は6月15日外相むてメモに，外相は熟心に日本から機城を取得しょう としているが坪上が金売却を提案するほどであるから日本はタイが欲しがる物沈䢻汇 持っていないのかもしれないと記した(56)。

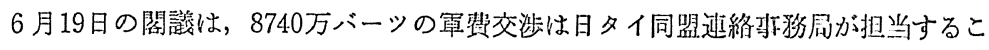
と，1540万については当座貸越を認めることを決めた。この店でピプーン首相は外相 に，ハシンコクでは激しく攻めているから東京でもこれと速携して交造するよらにとい ら訓令をディレーク大使に出すよら指示した(57)。外相はディレークにバンコクで月 本側に手交したものと同一の機栈・物品要求リストを送り「我々がいかに機峨を欲し ているかを十分認識して交渉するよらに(58)」と訓令した。また外相はピブーン古相 
東南フジフー歷史と文化一 No. 21, 1992

に，要求リスト中の僾先順位をつけることを求めた。

ところが首相の物が取れねば軍費は出さずとの強い指示に基き外相を中心に日本に 激しく迫った交渉はここで中断してしまう。7月21日に6月19日の閣議決定で交渉担 当者とされたチャイ日タイ同盟惪絡事務局長が新納と話し合いを始めるまで，草費交 渉は途切れてしまっている。しかも7月21日の会談でチャイは新納に，機峨取得では なく市場価格統制への協力を求めた。このようにタイ側の交渉空口が外相からピブー ンの腹心であるチャイに代りかつタイ側の要求内容も変化した。この変更はピブーン 首相の指示によるものであろらが，何故ピブーンがあれほど執念を然やした機械・物 品取得を更に綄けては追求せず市場価婪統制に要求を变えたかは不明である。それは 7 月21日にチャイが首相に具申したよらにインフレに詨しとにかく即効的効果を求め たから(59)であったかもしれないし，あるいは7月3日から5日まで訪タイした東条 首相が領土回復といら手土産を持って来たことが寄与したのかも知れない。

しかしその理由が何であれ 6 月にあれほど強行に交渉したにも拘らず機械・物品は 皆目入手できなかった経験を通して，日本の国打対する不信と見限りがピブーンの 心に生じていたことは間違いない。彼が日本を見限り始めたことは，合理的安全性が 確保されるまでは求めないと約して和りかつ日本側が橧がることが明白である金の現 送を公然と日本に蒸求したことに現われている。即ち8月 2 日から28日まで訪日中の ウィチット外相に刘し，8月10日付でピブーン首相（外相代行）は日銀にイヤマーク されている2476万1104.6グラムの金塊をタイへ早く現送できるように最善を尽して日 本と交涉せよと訓令した(60)。ウィチットに打診をらけた青木大東亜相はタイは金を 現送する権利は有するが，現送中の安全に不安があり空輸するには飛行機が不足して いると再洘を求めた。この要求が日本側にいかに不信感と不快感を生じさせるかはウ ィチットも十分認識していた。金準䚚を手元において国民の通貨への信頼を高めたい というタイ側の表面上の理由に刘し「日本は口では現送を認めるというが内心は現送 させたくはないことはよく判っている，乙かしタイの利益のため全量ではなくとも現 送する努加をしよう」と8月16日，箱根でのタイ側幹部会議でウィチットは語ってい る(61)。

バンコクでの笄频交涉に厌ると，7月21日チャイは新納に，時間のかかる機械取得 交涉の成果を待たずにタイの市場価格統制に日本の協力を求めたいと新しい提案をし た。機珹取得と電䨘供給とをリンクさせたタイ側の難題に苦しんでいた新納は「成果 が出るように尽力する。もし成果がなければ辞職する(62)」とこの新提案を微迎した。

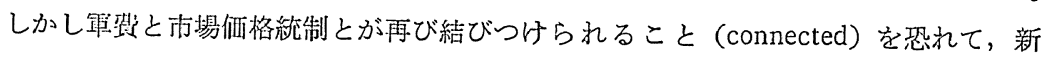


納は 7 月23日ワンを訪問し，両者は別個の問題である，もし両者を結合すれば東条首 相以下日本首脳部は強い不満を感じるし，タイはバーゲニングをしていると見る者も いよう(63)，と訪タイしたばかりの東条首相を持ら出して率制した。

同日，チャイから新納に統制しようとする物品リストと方法についての案が提出さ れた。その案は日本政府はリスト記戴の物品をタイ政府に引渡すこと, 引渡価格は東 京価格に必要経費及び10２0\%のコミッションを加克た簤国内であることを内容と し，リストには医楽品，缶ミルク，砂糖，マッチ，ロウソク，石けん，センイ制品，

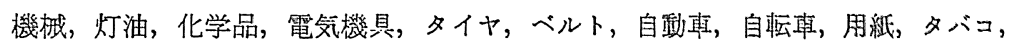
染料，ガラス製品，ビールなど57品目が举げられていた(64)。ほとんどが輸入に頼っ ていたタイの工業製品は当時は少量の上海からの翰入を除けば全て日本からの腧入で あった。そこで日本商社が翰入する工業亚品を東京での価格を基儊としてタイ政府が 日本政府の協力を学て買い上げ，安い公定価格で国民に売ろうとしたのがタイ侧のい ら市場価格統制策であった。7月26日新納はチャイに会い，市場価格統制は日本政府 保証ではなく坪上大使とチャイとの間の合意としたいこと，統制品数が多すぎるこ

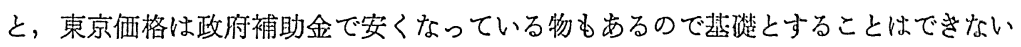
ことを告げ，一方，チャイの方は軍費を6000万に減額したいと昍し入れた。同日チャ イはデート・サニットウォン商相と相談し，綡制品数を14に絞った(65)。7月28日网 議決定がなされた。7月31日ウィチット外相は坪上大使に1943年下半期権劉として特 別円を対価として6000万バーツを供給する，もしこれで不足した場合は歌めて日朴侧 と協議する用意があるという趣旨の公文(66)を手交した。一方，非上も外相に范てだ

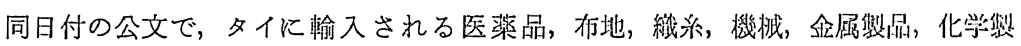

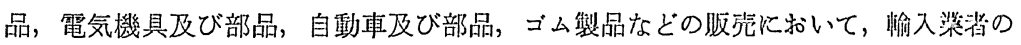
利益が20パーセントを超えないようにタイ政府が統制するといら原則を甚爑として而 国関係機関は協議してプランを作成する，そのプランを帮現するために必夏な指售な 日本政府はとる用意があると約した(67)。

ここに減額はされたが1943年下半期の電費協定が成立したのである。しかし成方㷋 未だ 2 カ月を経ない 9 月23日，坪上大使は外相に同年下半期分として浅争湤化により 8320万バーッの追加を求めるといら公文を提出した。下半期分として既に取得した 6000 万を加劣ると 1 億4320万の巨額に上り，その内訳は泰緬鉄道建設掏 3500 万，クラ 地陕横断鉄道建設費2000万，飛行場建設費1300万，陸軍6000万，海年1520万であっ た(68)。

7 月末に合意した市場価格統制についてはプランも末だ作成できず，8月に酫日大 
東南アジアー歷史と文化一 No. 21, 1992

使館が大東西省に提出した，首相自らが優先順位を付した機㑘・物品要求りストにも 何ら回答はきていなかった。タイ側には軍費額を抑えかつ金売却を求めるという従来 の原則に再び戻る以外に方法はなかった。10月 5 日チャイ日タイ同盟連絡事務局長は 大蔵省と協議して全額で4000万バーツを超光めのとしらち2000万は特別円と交換す るが，残りの半分即ち1000万については金売却を求めることを決めた。こののち新納 はチャイと数度にわたって交渉し, 満頌の供給を求め一方で金売却量を少なくしよう と努めた。チャイは(1)日本に2000万バーツについては特別円との交換を認める，(2)更 に6320万を日本が求めるならその半分につき金売却をすること，(3)今後もパーツ資金 との交換に扣いてはその半分につき金売却をすることの 3 原則を決め，自らが内閣書 記官長を辣任する内閣に報告した(69)。

10月17日閵誦は，6000万バーツは既に尽きてしまったという日本側に対し2000万の 当夾貸越を認め，しかし残りの額についてはその半分の金売却の原則を確認した。10 月19日新納は外相に覚書を提出し, 日本政府の訓令を次のように伝えた。即ち(1)軍費 は日タイ共通の大義のために絶対的に必要なるのであるから金売却を軍費供給の代償 として侾えるべきではない，(2)故に軍費供給額に対してその何パーセントにつき金を 壳却するという原則は受け入れられない，(3)しかし日本はタイ政府に最大の同情的考 箩を払いタイ政府が金売却が軍費とは別個の問題であると認めかつ量がタイが求める ほど多量ではなく，価格が生産費等を基礎としたfair and reasonableなものである なら金売却を行ならと。そして半分の3160万ではなく2500～2600万の金売却で妥協す るよう求めた(70)。

装10月20日には坪上と新納は外務省を訪問した。この席で坪上はワン顧問に「駐タ イ簐司令官中村明人中将がピブーン首相に会って既に説明したように日本軍は重要な 作戦を開始しなければならない。ピブーンはこれに援助すると答えている。日本軍の 当坐借越の2000万バーツは底をついて牤り至急首相に検討を打願いしたい」と申し出 た。更に新納は「日本政府は3000万バーツにつき金売却を認める，但し価格は 1 グラ ム 5 円95战である。(71)」とあとに続けた。彼の案は前日の提案よりは譲歩したもので あった。ウィチット外相が堅日大使に転出したので外相代行の任に就いたタムロンは 10月22日付で電费交渉の経過を首相に報告し, 金売却量3000万バーツは3160万に近い ので認めていいのではと具申し，価格については駐日大使館の日本での交渉結果を待 ちたいと報告した。ピブーンはこの具申を了承した(72)。

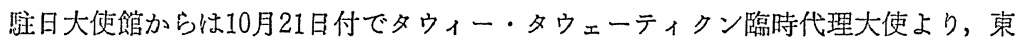
京での大蔵省原口局長との交渉の成果が報告された。その報告は金価格については進 
展はなかったが，金現送につき彼が「東京にイヤマークした金を监いていてもタイ图

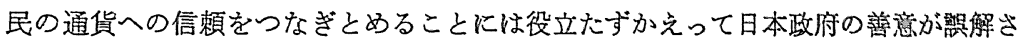
れる牤とれがある。」と現送を求めたところ原口はタイ側が危険負担をするならば現 送を政府に提案する用意があると答えたという報告であった(73)。10月22日付で渐納 は覚書を再度提出した。この覚書では 1 グラム 4 月 80 銭の金価格は猃への振替学予定 しない名目の価格である，1943年上半期軍費交步で50パーセントの金を1グラム4 月 80銭で売却した際新たに両者にとって公平で満足な原則を協議すると約束している， 央費は日タイ双方の大義と利益のために必要なるのである等々を主張し，1グラム5 円95銭を繰り返した(74)。タイ側はしかし敓歩しようとはしなかっだ。それは石井床 参事官が内密にということでウィチット前外相に，新納が個人の考克で金価格学上げ たがっていると内話したこと(75)が一因であったのかも知れない。

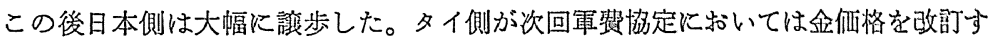
ると約束することを条件として従来の 1 グラム 4 円80銭で日本侧は妥恊したのであ る。即ち10月29日付で坪上大使は3000万円分の金をグラム当 4 冈 80 鈛で壳却する，但 し将来の売却に特いては1942年 5 月 2 日の協定覚整によらない a fair and reasonable price を双方が合意することを了解するという题旨の公文をタムロン外相代行に提出 し，外相代行も公文でこれに答えた(76)。

5 カ月に及んだ1943年下半期軍費交渉も，従来同様タイ侧の粘りによってタイ仪ぺ ースで終始した。この過程でタイ側が求め日本侧も合意した機械・物品の供給，门掂 価格統制には成果らしい成果は見られなかった。タイ侧は日本の来汃への不傮学览 え，戦中に执いてはそれまで要求したことのない给現送を求めるなでに至った。と惊 い光日本側にもこの時点では未だタイの求める金壳却には応じることができる亦少は 残っていた。

\section{V 戦局覀化と1944年上半期軍費交渉}

1943年半ば以後, 戦局の悪化が顕在化してきた。そのため日タイ双少はともに一阙 の苦境に立たされ，その軽減のためには互いに相対立する要求を一原強く主张せざる を得なくなった。加えて戦局の悪化は日タイの同盟関係を完全に形䠹化し，タイ侧は 敗戦後を考虑に入れた対日要求の度をも強めることになる。

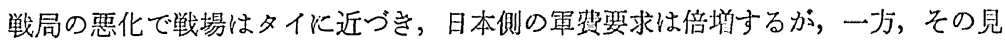
返りをタイに与をる日本の能力は，それが金塊であれ機栰・物品であれ，日々娍少し

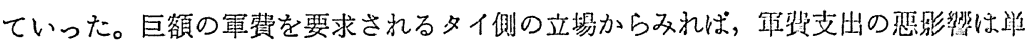


東南アシフー㡠史と文化一 No. 21, 1992

に経済面に限らず，国内政治の面にも队ぶようになった。即ち，国民のピブーン政権 への不満，不支持が增大したのである。罩費はその対価として得た特別円を準備金と する紙带增発によって供給されたため巨額の草蒷そのものがインフレを招くだけでな く，加えて潤沢な需費をるつ日本軍や納入商社が限向れた商品を市場価格を度外視し て買い漁るために，インフレは一層加速されたのである。工業製品の輸入杜絶とイン フレの影響の直揧をうけた人々は，世論形成の中心をなす都市住民である。更に彼ら

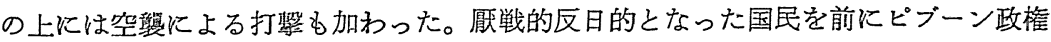

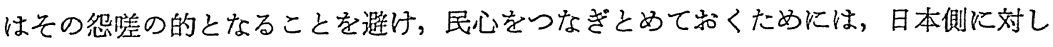
強い態度に出る必要があった。そのために日本側の要求とは正反対に軍費供給はでき るだけ少なく，見返りはできるだけ多くといら方針がとられたのは当然であった。更 に戦局の悪化は日本の敗戦を予想させ，敗戦とともに特別円の無価值化が見込まれた （77）のでタイ側は可能な限り金の売却を求めようとし，また既に日本でイヤマークさ れている金も手元に特くため相当の犠牲を払ってでも現送しよらと努めた。日タイの 互いに正区刘の要求が激突する中で1944年上半期の軍費交渉は行なわれた。

まず1943年半ば以後の日タイ同盟関係の形㔀化を日タイ双方の資料よりみておこ 5。194.3年 5 月 12 日, タイ閣議は戦争の展望についての判断を外務省を中心として極 秘に実施させることを決定した。5月24日ウィチット外相，ワン顧問，パック・ケー トサムリー総軍参謀長, チャイ日タイ同盟連絡事務局長らを中心とした検討の結諭 は，欧州の戦局がアジアでの勝敗を決定する，戦局を見極めるためにはもら少し待た ねばならないとしながらも，連合国の日本攻整の方向によってはタイが戦場となるこ とを予想する悲钼的なものであった。彼らはタイが戦場となるケースとして，ビルマ の日本焣がタイに逃げ込んだ場合, 或いは連合国軍のフィリピン占領後にインドシ ナタイに向けて攻整が失施された場合を考えた。日本が弱体化した時，反対側に寝

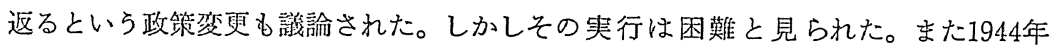
の1〜2月にはタイは空烓を受けるだろうと予想した(78)。

こののち 7 月 3 日, 東条首相が訪タイした。日本の占領地であるマレー, シャン州 の一部をタイ領に編入することを認めるといら土産をもっての訪タイであった。これ によってピブーン政㮔を抱き込も5とする日本側の期待は大なるものがあった。『大 本営機密践争日誌』の1943年6月30日の項は「三，東条総理八本日東京 7 出発シ南洋 万面旅行ノ梌二就ケリ『ビブン』『バーモ』ニ与フヘキ政治上ノ土産习持参シテ行ケ

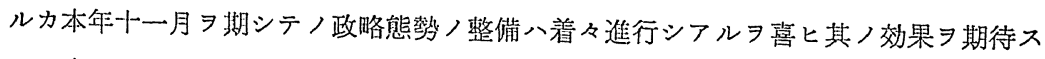
ルヤ大ナルモノアリ(79)」と記し，同じく8月20日の項には「与フヘキモノ八既二与 
日タイ同盟下の羁镂交渉

ヘタリ現地ニ於ケル日本側機関ハ泰国ヨ指導シ戦時態竻ノ整備強化卜大東覀戦争ノ協 力態勢ノ整備ニ邁進スヘキナリ……(80)」と記されている。

しかし日本側の期待とは逆に，9月 8 日のイタリアのバドリオ政権の降服頃より， タイ側の離反が日本側にも明白に認識されるようになる。当時参謀本部作戦課長であ

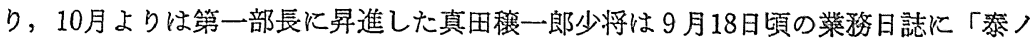
民心八伊ノ結果稍動摇 親英派大臬米英ノ勝利云々スルモノ少カラズ(81)」と記し, 9 月20日には「仏印ト泰 泰八最近オカシイ 電司令官 7 代へョ 伊太利ニスルナ (82)」と記した。

ピブーンは東条首相が期待した大東亜会議への参加を坪上大使や中村軍司令官の恐 請に(83)も拘らず拒えだ。坪上大使はピプーンは「対日屈服ヨリ国内政治情勞、紛紏 スヘキコト等ノ理由ヨリ日本カ強イテ上京ヨ強要スルナラ八議会 首相ヨ辞職シ新首相 7 東京ニ派遗致度意見ナルコト」を本省に伝えた(84)。大本営は 「『ビブン』ノ態度二懫慨セサルモノナシ 泰国ノ動摇八泰国ノ戦略的地位二鑑ミ忽 ニ出来サルラ以テ対策习深刻二研究セントス(85)」であった。

1943年12月19日の夜からバンコクはしばしば敵機の空襲をらけるよらになった。ピ ブーンはペッチャブーンへの遷都を急ぎ，これは日本侧には日タイ同盟からの成脱と うけとめられた。1944年2月1日の『大本営機密戦争日誌』は次のように記してい る。

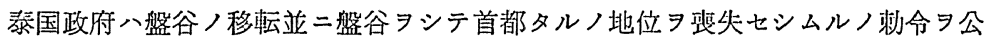
布セリ本回ノ泰国政府ノ沶レル措置八日泰同盟条約二基キ共同渽争完遂二苟進シ ッッアル同盟国ノ態度トシテ誠二遗憾ニシテ敵侧宣伝二乘セラルル腹大ナル

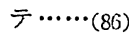

タイ㑡首脳の方も，タイ国民の偋戦気分や，タイ人が日本と運命をともにしような どとは考えてはいないことを鿵そうとはしなくなった。ディレーク駐日大使はその賦 をウィチット外相と交代し，1943年10月末から外相の職にあったが，1944年2月11日 訪タイした大東亜省南方事務局政務課長萩原徽と会見した際，萩原が現在日本は全 ての物を戦勝のために動員しており，あなたも在日時に御覧になったように政府は国 民に欲しがりません勝つまではと言わせている。贵国も同じように国民に説明して欲 しい。」と求めたのに対し，ディレークは「䎼情が異なる。贵国は生きるか死炇か价 がけで戦争をしている。タイ人にあなたのような説明をしたら，彼らはどうして触争 しなければならないのかと聞き返すでしょら」と答えている(87)。

1944年上半期の軍費交渉は，1943年12月16日坪上大使が渐納参事官とともにディレ 
東南フジフー䂑史と文化一 No. 21, 1992

ーク外相を訪問したことに始まる。坪上は年初にる敵はビルマやマラヤを攻撃するこ とが予想されるので日本側はそれに備えねばならず多額の軍費を必要とする，同盟条 約に從ってタイ側に援助を求めたい，タイ側は軍費と引き換えに金売却をこれまで求 めてきたが金売却は軍費とは別個の問題としたいなどと述べ，これらの点を首相に直 に会って合意しておきたいと申し入れた。外相の報告を受けたピブーンは，会ってる 何の役にも立たないと拒否するよう指示するとともに，軍費問題は12月18日の閣議に かけるよう命じた(88)。閣議は金の現送，産業機械・武器その他の物資を共存共栄の 原則に従い求めること，軍費の詳細を公開させてその節約を求めることなどの交渉方 針を決め，外相，蔵相，商相及び日タイ同盟連絡事務局長の 4 閣僚（チャイも国務大 臣）を軍費交渉担当者と決めた。(89)

12月23日坪上と新納は再び外相を訪問した。外相は軍費交渉を開始してよいと閣議 が決めたから日本側の準備が整えばいつでも開始できると告げた。坪上はこれに対 し，重要案件でありかつ本国政府の訓令るあるので是非首相に会ったのち交渉を開始 したいと再度要請した(90)。この日坪上は公文で，1944年上半期軍費要求額を公式に 伝えた。総碩は 2 億7500万バーツに上り，内訳は泰緬鉄道建設費5000万，クラ地峡棤 断鉄道建設費2000万，飛行場及び道路造成費3700万，木造船造船費 1500 万，陸軍 1 億 500万，海軍4800万であった。公文の中で戦争の激化により軍費は至急必要であり， かつ軍費のうちほぼ半分は戦後もタイの利益になる恒久的建造物建設に使うものであ るからとして，特別円を対価としてのバーッ供給を求めた(91)。ピブーンは坪上に再 度面会を求められ翌24日に面談した。坪上は陸海両武官を帯同し巨額の曘費が必要な 理由を雨者に説明させた。ピブーンは「軍費には反対しないが日本の方も我々を助け てくれ(92)」と答えた。

12月25日タイ側の担当閵僚たちはワン外務省顧問，ウィワットチャイ大蔵省顧問，

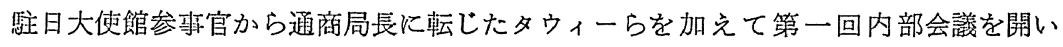
た。この会議で前日のピブーン坪上会談にも同席したチャイが対日交渉の 7 原則を提 案し承認された。その(1)は, 製紙機栈, 荷性ソーダ製造機, 紡績・織物機, 鉄道用デ イーゼルエンジン，タイヤを求める，(2) 1 グラム 4 円 80 銭の侕格で金を電費供給額の 50パーセントまで䁌入する。(3)日本船による金現送。これが不能の場合は日タイの協 力による現送，(4)兵器及び飛行機睛入，(5)軍費供給額削減，(6)タイ側で日本軍のため に軍用品を買い付けて日本軍に供給するとともに，日本軍が雇用するタイ人の高額の 当侄をも丽検討して日本簐の軍費支出を節減する，(7)医薬品の購入(93)，であった。 12月28日第一回日タイ軍費会議が開催された。タイ側出席者は第一回内部会議のメ 
ソバー，日本側からは坪上大使，石井康，新納克己の両参等官，陸海軍代表及び日銀 の中島福三郎が出席した。会議は擘頭より24日のピブーン発言さめぐって紛紏した。 坪上が「ピプーン首相は 2 億7500万バーツの額には反对しなかった，東京にす既に連 絡済であり，絶対に減額はできない。」と主張したのに対し，ピブーン腹心のチャイ は首相の意図は金額も含めて日本側と交渉することであると反論した。結局双方の策 の間で別の場で話し合うことにした。次いで外相は日本の対タイ援助について筫問し た。坪上は金売却の用意はあるが日本の金銨業は縮小されたので量は多くはない，日 本はタイの工業を振興する政策を有しているが船腹不足なので機械は直ぐには榆这で きないと答えただけで，具体的な回答はしなかった。

ワニット副蔵相は金現送と金売却問題を持ち出した。彼は戦前 2 隐バーッですった 紙幣流通量が 6 億バーツに増加している現実がある，もし金が現送されないと人民の 通貨への信頼が失なわれると語った。続いて外相が日本の友人として㸷うのだがと前 置して日本が金を売却するといら従来の政策を続けることがでさないとわかるとタイ 国民に誤解が生じ，それは日本に悪い絬果をもたらすであるらと半ば窝迫すると，水 上は今回日本が多量の金を売れないということは日本の戦力が弱っているといらこと ではない，日本の総力は向上している。この点をタイ政拊が正しく国民に祱明するよ らに求めたいと苦しい升明を行なった。タイ側は次いで国民生活に不可欠な織維倒晶

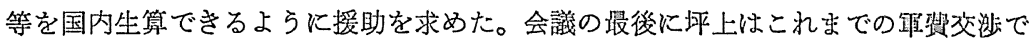
は結着までに時間がかかったので外部には日タイ間は親密ではなく日タイ協ういはうま

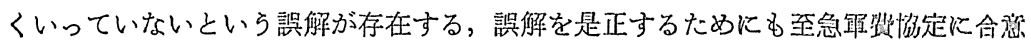
して欲しいと求めた。これに対し, 外相は軍費が至急必要なら当㚒貸越での引き壮し を認めるから支障はないと坪上の要望に応じなった(94)。更にチャイは烧勝のため

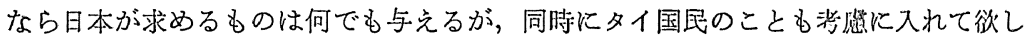

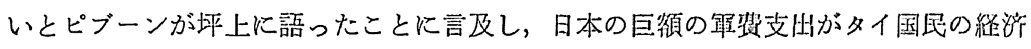
生活に及ぼす悪影響の大きさと，それが国民の政権不支持となってピブーン政椎が不 安定化することに日本側の注意を換起した。

12月30日に第 2 回目の日タイ会議が開かれた。今回は日本が売却できる金の遗と仙 格についてのより具体的交涉となった。タイ側はタイ通货への国民の信嗉碓保を理山 とし，また戦前の日本の金年間生産量は75トンであるから生産能力は十分あるとして， 従来通りの50パーセントの金壳却要求を繰り返した。これに刘し日本侧も訿時の噇桨

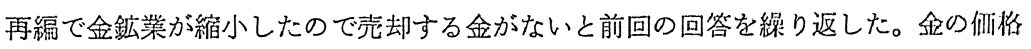
についてゥィワットチャイは，10月29日の公文で碓認した今後の皿格はa fair and 
東南アジアー歷史と文化一 No. 21，1992

reasonable priceを用いるとの合意を無視して 4 月80鉞を求め，新納は生産コストの 上昇を理由に 5 円95銭を鿁らなかった。欢方は各々の要求を持台帰り検討することに した。この会議で外相は金現送に特に強い関心を示した。彼は金の現送はタイ国民に タイ側が日本を助けてきた代儥として日本側もタイを助けているといらことを示す政 治的効果が大きいことを理由に挙げ，日本側に現送を求めた。そしてもし日本側たけ で現送が困難ならタイ側も協力すると付け加えた。日本側は現送中の危険負担者を明 碓にしないと現送はできないと答えた。更に商相はこの場でタイ側の求める機械・物 品リストを日本側に渡した(95)。

これら日タイ会議について外相から報告をうけたピブーン首相は，軍費は出しても いいが代りに物か金を必ずタイまで運んでこなければならないと指示した(96)。ピブ ーンは 8 月以来交渉を続けてきた金現送を字現させようという固い決意を有してい た。12月22日付でウィチット大使が，日本当局は現送費，保険料をタイが負担するな ら500キログラムの金を空輸することに合意する用意がある，日本側が現送コストを 負担すると定め心当初の原則には反するがコストは 1 万バーツ程度であるからタイ負 担で現送を推進したい。訓令を請らと言ってきた(97)。この電報はディレークとチャ イからピブーンに報告された。チャイはこれは日本側が現送コストを負担するといら 原則に反するので現在進行中の軍費交渉の中で交渉してみることにしたいと意見具申 した。しかしピブーンの答えは「直ちに現送に合意せよ。コストは我方で持つ。現送 に我方の人間が同行してくるべきである(98)」であった。

12月26日外相はウィチット大使に，現送コストは日本負担とすべきものだが首相の 命令により直ちに我方負担で現送すべし，但し今回は例外であることを確認して拈く ことと訓令した(99)。ピブーン首相は現送を急ぎ，空軍に命じてタイ側から受領にい くよう準䚚させた。1944年 1 月10日パック総軍参謀長は空軍の準備が完了したので早 く日本側と交渉を成立させることを外相に求めた(100)。1月12日付でウィチット大使 は青林大東亚相がタイ侧が現送コスト負担すれば500キログラムの金現送ができるこ とを約したと再び報告してきた。1月20日外相も再び現送を訓令した(101)。

一方, 年末の日タイ会議で歩み笴りのないままとなっていた軍費交渉は 1 月27日に 丽開された。この日，まずタイ側だけの内部会議が開かれ，この席で 1 グラム 4 円 80 践で簐軉の半分にあたる金を売却せよという要求を押し通すことを決定した。ついで タウィーが12月30日に日本侧に提出した要求物品リストに対し，日本側から何の回答 もないことを報皆すると，ボリパンユッタキット蔵相は「前回も日本から物品は何も とれなかった。一方日本軍は電費を引き出してしまった」と不満を漏らした。外相は 
何も得られなければ需費にサインしないまでたと応じた。タウィー通商局長は金を要 求するタイ側の意図を古京の日本側は政治的に見ている，つまりタイ側が英米が勝つ と信じているから金塊を要求するのだと見ている，このように日本側に不霓がある以 上金獲得や現送はタイが期待するほど䌪単にはいくまいと東京での経験に基き見通し を述べた(102)。

内部会議に引き続いて第 3 回日タイ軍費会議が開かれた。ディレークは直らに日本 側に検討結果を質問した。新納は政府の訓令によるとして，生虽コスト上蒋により 5 円95銭以下には下げられないこと，金生産縮小により売却量は2000万円が限度である こと及び金現送についてはタイ側が現送中の危険負担を負うなら好意的に検傠するを 答光た。日本側が初めて明らかにした金売却量は軍費の7.27パーセントにしか当らな い。タイ側はこの回答に驚さ，外相はその2000万円分は全て現送するように求めた。 チャイはタイは軍費供給の見返りとして東京に 6 億円近い特别円を持つことになる が，日本から輸入できる物は年間で5000万円にも達せずタイ国民は高物侕でものる買 わね侉ならないといら多大の犠牲を強いられている，日本から蕒入した鱼も現送でさ

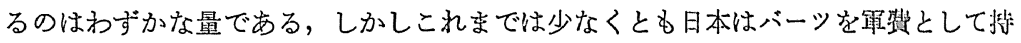
っていくがその半分については金を売却して返していると国民に説明することはでき たがと，日本側に理解と再考を求めた。外相は更にウィチットが交涉中の500キログ ラムの金の現送の他にも大量の現送を求めること及び直ちに会売却ができ欢とも翌年 以後売却してそれが軍費の50パーセントにまで達するよらに求めた(103)。

この会議ののち新納は，2月3日には外相やウィワットチャイを，2月4日にはチ ヤイを訪問し，日本側には売れる金塊の手持ちが本当になくこれ以上憏理である， 価格も5 円95銭から下げることは無理でむると説得して回った。新納との会見で山外

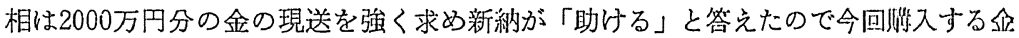
塊は全て空翰されると理解し内閭に報告した(104)。但しこれは外相の㟵解であること が值に判明した。

2 月11日大東亚省の萩原徾課長がディレークを訪問し，日本の㕸生应力について， 金鉱業は全く停止している，銅鉱の一部に金が混入して特り副应物として牟閶4000 5000万円の金が生産されるのみたと説明した(105)。2月7日に關かれたタイ侧の督贸 に関する内部会議では，藏相は1943年下半期軍費交渉時に票求した機城は今日に至る まで夫だ入手してないと語り，商相も12月30日にタイ側が求めた 7 品目のどれる人非 しておらずただ紡績機のみが現在海送中であると報告した(106)。

タイ側にも，日本の国力は既にタイ側の要求には応じられぬ程低下していることが 
東南アジアー歷史と文化一 No. 21, 1992

歷然としてきた。2月24日に開かれたタイ側の内部会議では次のよらな会話る交わさ れた。即ち外相がすし日本側が金塊がないと答えたら，我方はすう出せないのは確 か，それが最後の言藮かとだあ押しすべきである。そらしたら日本は敢えてそうたと 答えるだろうか。」と問うたのに対し，商相は「日本側は敢えてそうたと答觉るにち がいない。と答えた(107)。タイ側は日本側が大国の面子をつぶしても自己の能力欠 如を明白に認めるまでに弱体化したと見たのである。同日引き続いて開かれた第 4 回 目の日タイ軍費会謮では一カ月前と比し何の進展もなかった。

タイ側に対して与える物がなくなってしまった日本は長びく交渉の打開のためにピ ブーンとの会談を求めた。3 月13日坪上はロップブリーにピブーンを訪ねた。この場 には例によってチャイが同席した。坪上は(1)今回の軍費に関し5000万円分の金を売却 する，5ち2000万円については本年中に，残りを翌年より年間500万円ずつ3000万に 達するまで毎年壳却する。価格は 1 グラム 5 円78銭とする。(2)日本はタイに売却した 金㟴についてタイ側が現送のコストとリスクを負担すれば現送に応じる，という覚 書(108)を提出した。首相は「軍費は我々の 1 年間の国家予算よりも多いバーツを日本 に貸さねばならぬ問題である。我々は人民の通貨への信頼を担保するため金塊を得る ことに努めてきた。現在紙幣の量は多く一方物品はない。紙撆は紙切れ同様で何も買 らことができず国民は苦しんでいる。妥協の方法は金よりも物や機械をもらうこと,た とえば国民が必要な布地とか自動車部品とかタイヤを送ってくることだ。現在労務者 も紙暼は欲しがらない，儥金の代わりに工事の道具をもって逃げる者さえいる(109)」 と語った。坪上はピブーンは原則的に合意したと理解し, その旨本省にも報告し た(110)。

しかしタイ側の行動は遅く，坪上の覚書が外務省に届いたのは 3 月18日，タイ㑡軍 費関倸闑僚が検討したのは 3 月20日であった。3月30日になって坪上は結着を促進す るため 3 月13日の覚書と同文の公文を外相に提出した。同時に12月30日のタイ側の商 品要請リストへの回答を覚畫として提出した。タイ侧が求めた物のらちタイに到着し ていたものは5000䥔の紡績機械と110の織機に過ぎなかった(111)。この席で坪上はデ ィレーク外相とチャイ外相代理を前に早期結着を求めた。チャイはロップブリー会談 でピブーンが述べた布地の作を持ち出し，日本政府に1700万メートルの布地を要請し た。彼はこの難題を持ち出しながら，もしこれだけの量の布地をタイ政府が入手でき ればバンコクの日本人繊維商には大打慗か委しれませんがと日本商人の売り惜しみを 皮肉った。坪上は休㗇帰国を理由に電費の速やかな結着を求めたが，タイ側は先ず布 地についての回答を求めて結着を拒否した。坪上は「軍費交渉をいろいろいって引き 
延すのは日タイ関係にとって宜しくない(112)」と怒るが何の効果るなかった。外相の

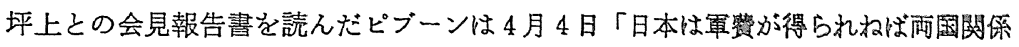
はよくないと文句をつけるが，我々る布地が得られ权ば両国関保はよくないと公㛭す べきだ」と会見報告畫に書きつけた。4月 5 日の閣議は，金価格は1グラム 5 円 30

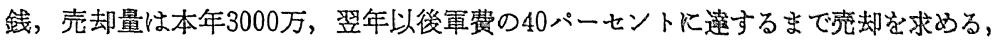
金現送及び日本からの物品獾得を促進すると決定した(113)。タイ側は相变らずの強硬 方針で軍費交选を妥結する道は求めなかったのである。

4 月 6 日坪上は再びピブーンと会見した。この席で日本侧は本年につき 3000 万円分 の金売却，以後每年 500 万円分を 4 年間壳却すると㜔歩を行ない，これにピブーンも 応じた。また金現送については戦中に限り現送費保険料はタイ㑡が负担することで合 意した。この合意は翌 4 月 7 日の閣議で了承された(114)。

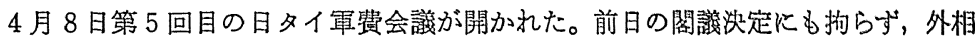
はピブーンの命令によるとして金贈入洒格を 5 円78銭で応じた見返りに金の現送は日 本負担で报願いしたいと言い出した。新納は金現送は合理的安全性がある揚合のみ日

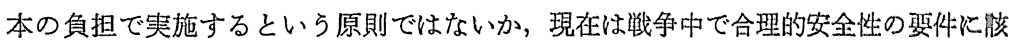
当しないだけではなく，戦争に必要な飛行機を現送に使用するのは澄性が大さすざる と反椧した。この席で日本侧は翌 9 日に坪上が日本に出発する前に合意したいと強く 要請した(115)。漸くこの日，(1)金壳却の罝，洒格，及び战後の金現送の危除负担につ いてのタイ側公文，(2)1944年上半期軍費として 2 億7500万バーッを特别円を刘们とし

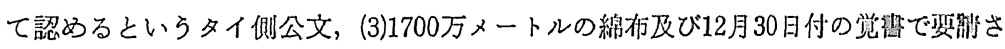
れた物品を1945年 3 月末までに供給するように努力するとい5日本侧公文が各々非交 された(116)。ここに12月半ば以来 4 カ月近くを要した管留交涉は成立した。

この交渉の過程でタイ側は日本の国力の衰克をまざまざと知った。增大する朴侧 の軍費要求に対し，タイが帮際に獲得できた見返りははんのかずかであった。经覞送 については44年 2 月 1 日付でウィチット大使が「タイが金琴送を求めるのは反权㠹侧 の勝利を予期しているからだと日本に䇝われないよう慎相にやらねばならない(117)」 と言ってきたが，ピブーンは意に介せず現送に埶着した。しかし彼の首相在任中の 7 月までには実現しなかった。

$$
\text { おわりに }
$$

本稿は日タイ同盟の食の下で継続的に行なわれた電贺交渉をできるたけ䦼料に忠笑 に描き出すことで，日タイ同盟の実態の一側面を明らかとしよらと陚みた。ここで明 
東南アジア一臨史と文化一 No. 21, 1992

らかになったことは，タイ国民を支持基盤とするピブーン政権は国民の利益を犠牲に して日本側に応じことはなく，逆にタイ側の利益を最大限にするために粘り強い交 渉を行なったことである。タイ側が軍費交渉において最重要と考えた利益は同盟初期 と戦局が悪化した時期とでは異なっていた。初期においては通貨の安定のための金獲 得であり，次いで国民の経済生活における物資不足，物価高騰に対応して，国内工業 育成のための日本からの資本財翰入及び工業製品の輸入要求であった。戦局が悪化し 日本の国力減退が明白となると金現送要求となった。当初は大蔵省，外務省の判断で 交渉が行なわれたが，中期以後，国民生活の悪化に直面したピブーン首相のイニシャ ティブが強くなった。

一方，本稿が日本側史料の欠如によりタイ側史料に基本的に依机せざるを得なかっ た点は割引いて考えられるべきかもしれないが日本側の交渉のまずさが目立つ。日本 側がお題目の如く唱える同盟の大義や東京の意向の効力は弱く，かつ本省と駐タイ大 使館間及び大使館内の統一珄の欠如のためにタイ側に譲歩して結着せざるを得なか った。特に日本に与学る物がなくなった中期以後は，交渉において日本の無力さをさ らけ出すこととなった。この頃より日本軍のタイへの増強が始まり, 交渉において武 力の役剖が增大するようになるであろら。しかしその時期は1944年半ば以降クアン内 閣になってのことでありこの時期については別稿に譲るものとする。

[付記]財団法人大和銀行アジア・オセアニア財団の助成金により本研究のための 資料収集調査の一部を契施した。ここに感謝の意を表する。

注

(1) Direck Jayanama, 1970, Thai kap Songkhramlok khrang thi 2, 2nd ed., Bangkok : Thaiwathanaphanit. pp. 168-173.

（2）原寿雄手記，1968，「储忘録一一青年将校時代」p.13. 尚，正確には軍費は 識会通過を要しない,この点は原の記憶違い。

（3）雭苦交涉についての日本側史料は外交史料館所蔵の「大東业戦争関係一件, タイ国問題，進駐軍軍費問題」をみることができるのみである。

（4）『国際経済週報』，1941年12月20日号，p. 24 .

（5）三井調査1941年 2 月 4 日，英国ノ泰国ニ対スル経済的地位』（成蹊大学図書 館三菱経済研究所資料)

（6）『国際経済週報』，1941年11月 1 日号，p. 38 .

（7）『貿易統制会会報』，第 1 巻第 3 号（1942年. 7 月）， p. 5 . 
（8）『ェコノミスト』，1941年9月1日号，p.3.

(9) Direck Jayanama, 1970, pp. 82-83.

(10) Samnakgan Lekhathikan Saphasetthakit haeng Chat, 1952, Sathanakan Setthakit khong Prathet Thai, Bangkok, p. 38.

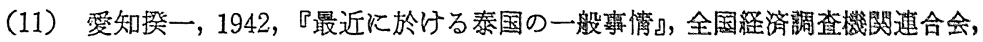
p. 15 .

(12) Thanakhan haeng Prathet Thai (タイ国銀行), 1972, Prawat las kanda. mnerngan khong Thanakhan haeng Prathet Thai, Bangkok, p. 10.

(13) Thanakhan haeng Prathet Thai, 1961, Wiwatchaiyanuson, Bangkok, p. 77.

（14）大蔵省為替局，1942，『日泰経済交渉/概要』（国立公文靚館所蔵）

(15）愛知揆一，1942，p.17.

（16）大藏省為替局，1942.

(17) Direck Jayanama, 1970, p. 84.

（18）愛知揆一，1942，p.2. プリディー藏相と大野顧問の対立定示すタイ侧这料 はWW2/2:7/1.

（19）前出外交史料館所蔵「進駐軍軍費問題」及び WW2/2:7/1.

(20) Thanakhan haeng Prathet Thai, 1961, p. 80.

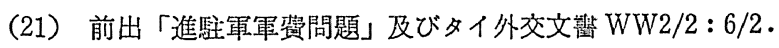

(22) Thanakhan haeng Prathet Thai, 1961, p. 77.

（23）大蔵省為替局, 1942, pp. 1-2.

(24) Thanakhan haeng Prathet Thai, 1961, p.67. 及び Thanakhan haeng Prathet Thai, 1972, p. 11. 及び大蔵省為替局, 1942, pp.3-13.

（25）大藏省為菼局，1942， p. 16.

（26）南方会編，1969，『南方の思出』(非売品), p. 233.

(27) Thanakhan haeng Prathet Thai, 1970, Banthukgan khong Prayad Buranasiri, Bangkok, p.5. 及び大藏省為替局, p. 54.

(28) Thanakhan haeng Prathet Thai, 1982, Thiraluk nai kanpert Akhan Samnakganyai Thanakhan haeng Prathet Thai, Bangkok, p.77.

(29) Thanakhan haeng Prathet Thai, 1972, pp. 11-12.

（30）大蔵省為替局，1942，p.23.

(31) Thanakhan haeng Prathet Thai, 1961, p.81.

(32) Thanakhan haeng Prathet Thai, 1962, Thiraluk Wankhroprop pithi20, 
東南アジフー歷史と文化一 No. 21，1992

Bangkok, pp. 11-12.

（33）WW2/2:6/4.「1942年11月30日付日本軍軍費のための当座借越 要請に関す る記録」

(34) Thanakhan haeng Prathet Thai, 1970, p.5.

（35）WW2/2:6/4. 及び前出外交史料館所蔵「進駐軍軍費問題」

(36) WW2/2:6/4.

（37） WW2/2:6/4. 坪上大使よりウィチット外相宛 $F / 625 / 17$ 公文及びウィチッ 卜外相より石井康臨時代理大使宛公文。

（38）WW2/2:6/4. 石井康臨時代理大使よりウィチット外相宛 $F / 44 / 18$ 公文。

（39） WW2/2:6/4. タイ外務省1945年 8 月15日作成「1943年上半期日本軍軍費 に関する記䟿」

（40）WW2/2：6/4. 1943年 3 月19日付ウィチット外相の “Memorandum regard. ing Funds for Japanese Military Expenditure".

(41) WW2/2:6/4. ディレーク大使発外相宛 $111 / 2486$ 電。

(42) 注(40)に同じ。

（43）WW2/2：6/4. 1943年 3 月25日付ウィチット外相より蔵相宛文書。

（44）WW2/2:6/4. 1943年 3 月27日付蔵相より外相宛 T. 380/2486文書。

(45) WW2/2:6/4. 1943年 4 月 7 日付新納作成 “Memorandum regarding Funds for Japanese Military Expenditure".

（46）WW2/2:6/4. 1943年 4 月12日付外務省顧問より大藏省顧問宛文書。

（47）WW2/2：6/3．1943年4月19日付商務省作成「インフレに関する日本側との 交渉記録」

（48）注(46)に同じ。

（49）WW2/2:6/4. 1943年4月16日付チャイ内閣書記官長代行より外相宛 T. $2853 / 2486$ 文幚。

（50）WW2/2:6/4. 坪上大使よりウィチット外相宛 $F / 118 / 18$ 公文。

（51）WW2/2:6/4. 本私信は経済問題，領土問題の二部からなる長大なるの。

（52）WW2/2：6/3. 1943年6月14日付外相よりピブーン首相宛日本軍雪費に関す る11474/2486文琵。

（53） WW2/2:6/3. 1943年 6 月 5 日付ワン作成の「第 1 回日タイ軍費委員会議事 䟿」及びメモ。

（54）WW2/2:6/3.「1943年 6 月10日第 2 回日タイ軍費委員会議事録」 
（55）注(52)に同じ。

(56) WW2/2:6/3. 1943年 6 月15日付蔵相より外相宛文書。

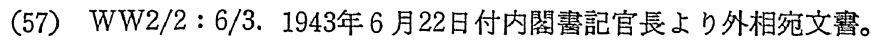

（58）WW2/2:6/3. 1943年 6 月26日発外相よりディレーク大使宛電。

（59）WW2/2:6/5. 1943年 7 月21日付チャイ大佐よりピブーン首相宛文凿。

(60) WW2/2:6/5. 1943年 8 月 10 日発外相より駐日大使宛 $340 / 2486$ 䉓。

（61）WW2/1：6/5. 1943年 8 月16日箱根富土屋ホテルに括ける経済問題に関する タイ側内部会議記録。

（62）WW2/2:6/5. 1943年 7 月21日付チャイ大佐より商相宛文䁌。

(63) WW2/2:6/5. 1943年 7 月23日付ワン外務省顧問記録。

（64）WW2/2:6/5. 1943年 7 月23日付チャイ大佐より新納宛文韵である

"A List of the commodities over which my Government would like to exercise control, together with our proposal in regard to their delivery".

（65）WW2/2:6/5.「1943年 7 月27日外務省に批ける日本雵曘费に関するる議孙録」

（66）WW2/2:6/5. 1943年 7 月31日付ウィチット外相より坪上大使宛17154/2486 公文。

（67）WW2/2:6/5. 1943年 7 月 31日付坪上大使よりウィチット外相宛 $F / 217 / 18$ 公文。

（68）WW2/2:6/5. 1943年 9 月23日付坪上大使よりウィチット外相宛 $F / 275 / 18$ 公文。

(69) WW2/2:6/5. 1943年10月12日付チャイ少将より蔵相宛文望。

（70）WW2/2:6/5，1943年10月19日付新納作成の “Memorandum Re Military Expenditure".

(71) WW2/2:6/5. 1943年10月21日付ワン外務省顧問記録。

（72）WW2/2：6/5. 1943年10月22日付タムロン外相代行より首相宛1943年下半期 日本軍費に関する文書。

（73）WW2/2：6/5.1943年10月21日発タゥィー臨代より外相宛464/2486笔。

(74) WW2/2:6/5.1943年10月22日付新納作成の “Memorandum Re Price of Gold".

（75）WW2/2:6/7.「1944年 1 月 2 日外務省における1944年上半期日本軍軍特に 関する会議（第 3 回）議事録」

（76）WW2/2：6/7. 1943年10月29日付坪上大使よりタムロン外相代行宛 F/313/ 
東南フジアー歷史と文化一 No. 21, 1992

18公文及び同日付タムロン外相代行より坪上大使宛 $25785 / 2486$ 公文。

(77) Thanakhan haeng Prathet Thai, 1961, p. 80.

（78）WW2/1:1/18.「1943年5月24日外務省における会議記録」

（79）『大本営機密戦争日誌其ノ八』（防衛研究所所蔵）なお，ビブンとはピブー ンのことである。

(80) 同上。

（81）『真田䖽一郎少将日記』(防衛研究所所藏）

(82) 同上。

（83）中村明人，1958，『ほとけの司令官一辠タイ回想録』，日本週報社，pp. 90-

91.なお篗者は本書をタイ語訳し1991年末に出版した。

（84）『大本営機密戦争日誌其ノ十二』の10月9日の項。

(85) 同上。

（86）『大本営㙨密戦争日誌其ノ十三』

（87）WW2/2:6/7。「1944年 2 月11日のディレーク外相会見記録」な拈本文畫の 原本は篗者所蔵の「ディレーク・チャイヤナーム文畫」中に有る。

（88）WW2/2:6/7. 1943年12月16日付外相の首相宛報告文。

（89）WW2/2:6/7. 1944年 2 月 9 日付外相より内閣書記官長宛文凄。

（90）WW2/2:6/7.「1943年12月23日の外相会見記録」

（91）WW2/2:6/7. 坪上大使よりディレーク外相宛 $F / 370 / 18$ 公文。

（92）WW2/2：6/7.「1943年12月25日外務省に括ける1944年上半期日本軍軍費に 関する会議（第 1 回）議事録」

(93) 注(92)に同じ。

（94）WW2/2：6/7.「1943年12月28日外務省における1944年上半期日本軍軍費に 関する日タイ合同会議（第 1 回）議事録」

（95）WW2/2：6/7.「1943年12月30日外務省に晾ける1944年上半期日本軍電費に 関する日タイ合同会議（第 2 回）議事録」

（96）WW2/2:6/7. 1944年 1 月 5 日付外相より首相宛報告へのピブーン首相の書 き込み。

（97）WW2/1：6/5. 1943年12月22日発ウィチット大使より外相宛565/2486電。

（98） WW2/1：6/5. 1943年12月23日付経済局東洋課文書へのピブーン首相の書き 込及。

（99）WW2/1：6/5. 1943年12月26日発ディレーク外相よりウィチット大使宛628/ 
日タイ同盟下の軍㗆交渉

2486電。

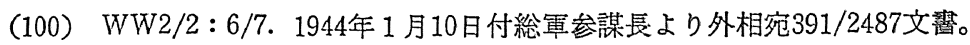

（101）WW2/2：6/7. 1944年 1 月20日発ディレーク外相よりウィチット大使宛43/ 2487電。

（102）WW2/2：6/7.「1944年1月27日外務省に就ける1944年上半期日本軍曘费に 閔する会漾（第 4 回）綠事録」

（103）WW2/2：6/7.「1944年 1 月27日外務省に和ける1944年上半期日本軍軍費に 関する日タイ合同会議（第 3 回）議事録」

（104）WW2/2:6/7.「1944年 2 月 3 日の外相会見記録」及び1944年 2 月 9 日付外 相より内閣畫記官長宛報告文。

（105）注(87)に同じ。

（106）WW2/2：6/7.「1944年 2 月 7 日外務省に拈ける1944年上半期日本軍軍費に 関する会議（第 5 回）議事録」

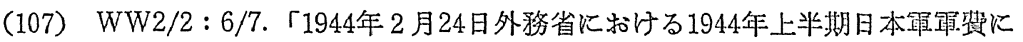
関与る会議（第 6 回）議事録」

（108）WW2/2:6/7. 1944年 3 月13日付 “Memorandum Re : Selling and Transportation of Gold".

（109）WW2/2：6/7. 1944年 3 月13日付アート・チャローンシン少佐記録。

（110）WW2/2：6/7. 1944年 3 月20日発ウィチット大使よりディレーク外相宛120 /2487電。

（111）WW2/2:6/7. 坪上大使よりディレーク外相宛 $F / 75 / 19$ 公文。

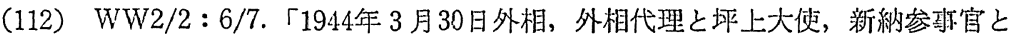
の会見議事録」

（113）WW2/2：6/7. 1944年 4 月 7 日付チャイ内閣甾記官長よりディレーク外相 宛文輩。

（114）WW2/2：6/7. 1944年 4 月10日付チャイ内閣䍣記官長よりディレーク外相 宛文量。

（115）WW2/2：6/7.「1944年 4 月 7 日外敄省に少ける1944年上半期日本軍軍费に 関する日タイ合同会議（第 5 回）議事録」

（116）WW2/2:6/7. 1944年 4 月 8 日付ディレーク外相より埭上大使宛 $4535 / 2487$ 公文，及び同じく4540/2487公文。坪上大使よりディレーク外相宛 $F / 87 / 19$ 公文。 （117） WW2/1：6/5．1944年 2 月 1 日発ウィチット大使より外相宛50/2487電。 


\section{Military Expenditure Negotiations under the Japan-Thai Alliance Pact of 1941 1944}

\section{Eiji MURASHIMA}

Actual state of Japan-Thai relations under the Pact of Alliance between the two countries during the Second World War is a theme of seemingly great interest in both modern Thai and Japanese history, but very little specific research on the subject exists today. This is because it is impossible to draw a detailed picture of the situation by using only Japanese materials, since there exists almost nothing. As to the Thai materials, there are plenty of diplomatic records, which, unfortunately, have yet to be examined thoroughly.

This study is an attempt to clarify some aspects of the real conditions 0 Thai-Japan relations under the Alliance Pact through investigating these dipf lomatic documents, especially those concerning military expenditures for the. Japanese forces.

From the start of the war, the Japanese Government, relying on the Alliance Pact, demanded that the Thai Government supply baht funds to cover the military expenditures by the Japanese forces stationed in Thailand. Such expenditures included not only every cost of maintaining Japanese soldiers and sailors physically, but also the total cost of constructing military railways, strategical roads, aerodromes, wooden ships, military positions, and so on. Therefore, whether it was supplied fully or not was a matter of life and death for the Japanese forces. The amount was agreed to after negotiations between the Japanese Embassy in Thailand and the Thai Government conducted every 6 months. A mere 15 million baht were paid for the first half of 1942, but the amount increased to 470 million baht for the first half of 1945 . To meet the Japanese request, the Bank of Thailand, which was established according to demands made by the Japanese Government in late 1942, issued baht notes against "special yen" as reserves. In addition to imported goods shortage during 
wartime, issuing unlimited amounts of baht notes caused a deteriorating inflationary effect on the Thai economy. The amount of notes in circulation increased form 275 million baht at the end of Nov. 1941 to 1,993 million baht at the end of Aug. 1945. The consumer price index in Bangkok increased more than three times within the 2 years following the beginning of the War.

The first agreement for the first half of 1942 signed on 20 Dec. 1941 took the form of a loan which would be repayed in gold. Thereafter, on 21 April 1942 the Wanit economic misson visited Japan and agreed that all payments, including both commercial and non-commercial, between Japan and Thailand were to be made in special yen. Relying on this agreement, a system of granting reciprocal credit was adopted. The Japanese Government expected to get baht funds in exchange for special yen without repaying in gold. In spite of such expectetions, however, the Thai Finance Minister urged Japan to sell gold against special yen up to 50 percent of the baht funds supplyed by the Thai Government in order to stabilize its currency, and they finally succeeded in obtaining that amount of gold. They continued to insist on purchasing gold against special yen in the negotiation concerning military expenditure for the first 6 months of 1943.

In the negotiations for the latter half of 1943, they changed their policy from demanding gold to demanding machines and staple goods, such as textiles and medicine. This policy change was initiated by Prime Minister Pibul, who regarded himself as the true guardian of the interest of the Thai people. Given that Thailand was now suffering from a devastating economic situation, naturally Pibul was anxious about losing public support. The Japanese Ambassador agreed to assist in sending some machines and goods and also promised to assist in the control of the sale of essential commodities imported from Japan. The Japanese Government, however, failed to send any machines or goods to Thailand. The Thai Government realized the real economic situation in Japan. Moreover the surrender of the Badoglio Government in Sept. 1943 made them anticipate Japan's defeat in the not too distant future. For saving their gold earmarked in Tokyo, they began too demand its transportation to Thailand ignoring the written agreement with Japan, in which they agreed not to request 
東南フジフー歷史と女化一 No. 21，1992

gold transportation until it could be sent with reasonable safety.

Through all these military expenditure negotiations, the author shows that the Thai Government devoted all their energies to the interest of the Thai nation without paying attention to the cause of the Alliance, an important theme emphasized by the Japanese side.

(速絡先 : 成睖大学文学部 